\title{
Study of Nitric Oxide Level in Chronic Hepatitis C Egyptian Patients: Relationship to Viremia Level and Antiviral Therapy response
}

\author{
Authors \\ Mohamed Ahmed Kasem ${ }^{1}$, Akram Abdelmoneim Deghady², Essam Eldin Saeed Bedewy \\ Ayman Mohamed Shamseya ${ }^{3}$, and Manar Mohamed Rashad ${ }^{1}$ \\ ${ }^{1}$ Department of Tropical Medicine, Faculty of Medicine, University of Alexandria, \\ ${ }^{2}$ Department of Clinical Pathology, Faculty of Medicine, University of Alexandria, \\ ${ }^{3}$ Department of Internal Medicine, Faculty of Medicine, University of Alexandria \\ Email:Dr.mohamed_a_kassem@hotmail.com,Akram61@yahoo.com,essambedewy75@gmail.com, \\ dr.ayman1977@gmail.com,Sweetmony83@hotmail.com \\ Corresponding Author \\ Dr Ayman Mohamed Abdou Shamseya \\ Lecture, Department of Internal Medicine, Faculty of Medicine, University of Alexandria, Egyp \\ Address: 21, Elsayed Radwan St, Miami, Alexandria, Egypt \\ E-mail: dr.ayman1977@gmail.com, Phone: +201222903176
}

\begin{abstract}
Background and aims: Hepatitis $C$ virus $(H C V)$ infection is a serious global health problem that affects about 180 million people worldwide. Egypt has a very high prevalence of HCV and a high morbidity and mortality from chronic liver disease, cirrhosis, and hepatocellular carcinoma. The goal of antiviral therapy is to cure hepatitis $C$ via a sustained elimination of the virus, which is achieved if the HCV RNA remains negative six months after the end of treatment (sustained virological response, SVR). Nitric oxide (NO) is a short, lived, highly reactive free radical, influences many physiological processes in virtually every organ and tissue. Aim was to study the role of nitric oxide level in chronic hepatitis $C$ patients as a predictor of response to antiviral therapy in relation to the level of viremia.

Patients and methods: 60 subjects were eligible for the study and were classified into two groups: Group I: Included forty HCV patients who were candidates for initiation of antiviral combination therapy, also they were followed 12 weeks after. Group II: Included twenty adult apparently healthy volunteers negative for both HBsAg and HCV Ab and have no clinical or laboratory signs of liver diseases.

Results: there was a significant difference in the post-treatment level of NO between responders and nonresponders where the level of $N O$ was higher in responders than in non-responders.

Conclusions: The study concluded that increasing level of serum NO in HCV patients in response to antiviral therapy can be considered as a predictor of response.

Key-words: antiviral therapy, hepatitis, nitric oxide
\end{abstract}




\section{Introduction}

It is now well established that HCV is a global health challenge, with an estimated 130-180 million chronic infections (2-3\% of the global population). ${ }^{[1]}$

The lowest prevalence $(0.01 \%-0.1 \%)$ has been reported from countries in the United Kingdom and Scandinavia, the highest prevalence (15\%-20\%) has been reported from Egypt; where the prevalence of infection increases steadily with age, and high rates of infection are observed among persons in all age groups. ${ }^{[2]}$

Egypt has a very high prevalence of $\mathrm{HCV}$ and a high morbidity and mortality from chronic liver disease, cirrhosis, and hepatocellular carcinoma. ${ }^{[3]}$ Approximately $20 \%$ of Egyptian blood donors are anti-HCV positive. ${ }^{[3]}$ The strong homogeneity of HCV subtypes found in Egypt (mostly 4a) suggests an epidemic spread of $\mathrm{HCV} \cdot{ }^{[3]}$ Since a history of injection treatment has been implicated as a risk factor for $\mathrm{HCV}$ infection, a prime candidate to explain the high prevalence of HCV infection in Egypt is the past practice of parenteral therapy for schistosomiasis. ${ }^{[3]}$

HCV prevalence levels in Egypt indicate uneven geographic distribution, with higher HCV prevalence found in rural areas compared to urban settings, and in Lower Egypt compared to the rest of the country. ${ }^{[4]}$ The factors contributing to the spatial heterogeneity are not well understood, but disparity in the intensity of past parenteral antischistosomal therapy campaigns has been proposed as a cause of the geographical variation. $^{[4]}$

Chronic hepatitis $\mathrm{C}$ viral infection should be considered in every patient presenting with clinical, morphological or biological signs of chronic liver disease. ${ }^{[5]}$ When chronic hepatitis $\mathrm{C}$ infection is suspected, screening for $\mathrm{HCV}$ antibodies by 2nd or 3rd generation EIAs is adequate because their sensitivity is $>99 \% .{ }^{[5]}$ When anti-HCV antibodies are detected, the presence of HCV RNA has to be determined in order to discriminate between chronic hepatitis $\mathrm{C}$ and resolved $\mathrm{HCV}$ infection. ${ }^{[5]}$

The goal of antiviral therapy is to cure hepatitis $C$ via a sustained elimination of the virus, which is achieved if the HCV RNA remains negative six months after the end of treatment (sustained virological response, SVR). ${ }^{[6]}$ Importantly, long-term benefits of SVR are the reduction of HCV related hepatocellular carcinoma and overall mortality. ${ }^{[6]}$ In 2011, the first direct antiviral agents (DAA) were approved for patients with HCV.

During the last decade, tailoring treatment duration and dosing according to individual parameters associated with response has improved SVR. ${ }^{[7]}$ Predicting SVR before the start of antiviral treatment, helps in making treatment decisions. ${ }^{[7]}$ Important baseline factors associated with SVR to PEG-IFN/RBV are the HCV genotype, the degree of liver fibrosis and steatosis, baseline viral load, presence of insulin resistance, age, gender, body mass index, ethnicity, and HIV coinfection. ${ }^{[7]}$

Nitric oxide (NO) is a short, lived, highly reactive free radical, influences many physiological processes in virtually every organ and tissue. ${ }^{[8]}$ It diffuses freely across membranes, which helps being ideal for transient paracrine and autocrine signaling. ${ }^{[8]}$ It exhibits a remarkably broad spectrum of functions, including neurotransmission and memory formation, regulation of blood pressure, modulation of the bacterial and tumorcidal activity of macrophages, and liver regeneration. This small unstable gaseous, free radical performs its complex tasks by acting as an intra- or extra cellular messenger molecule. ${ }^{[8]}$

Three main NOS isoforms have been identified and cloned so far; nNOS (neuronal or type I), iNOS (inducible or type II), and eNOS (endothelial or type III).In addition ,new isoforms or mitochondrial variants of NOS (mtNOS) have been described recently in rat liver, thymus, and brain. ${ }^{[8]}$ eNOS and nNOS are constitusevely expressed and produce relatively small amounts of NO${ }^{[8]}$ On the other hand, iNOS is up regulated under a number of conditions, including endotoxaemia, hemorrhagic shock ,ischemia, reperfusion, hepatitis and liver regeneration. ${ }^{[8]}$ 
Under normal conditions, only eNOS is present in the liver, and the low level of NO is produced by eNOS regulates hepatic perfusion, among other functions. ${ }^{[8]}$ However, iNOS is readily up-regulated in the liver under a number of stressful conditions as endotoxaemia, hemorrhagic shock, ischemia, reperfusion, sepsis, infection, hepatitis, ozone exposure, and liver regeneration. ${ }^{[8]}$ Once iNOS is expressed, large amounts of NO are generated in the liver in a sustained fashion, which functions as an important regulator and effect or during inflammation and infection. ${ }^{[8]}$

The present study was carried out to study role of this molecule as a predictor of response of HCV Egyptian patients to combination antiviral therapy, and also effect of therapy on its level in both responders and nonresponders. The aim of this work was to study the role of nitric oxide level in chronic hepatitis $\mathrm{C}$ patients as a predictor of response to antiviraltherapy in relation to the level of viremia.

\section{PATIENTS AND METHODS:}

This study was a Prospective cohort study which was conducted at Alexandria Main University Hospital, on 60 subjects classified into two groups:

- Group I: Included forty HCV patients who were candidates for initiation of antiviral combination therapy, also they were followed 12 weeks after.

- Group II: Included twenty adult apparently healthy volunteers negative for both HBsAg and HCV Ab and have no clinical or laboratory signs of liver diseases.

Patients with concurrent HBV infection, alcohol induced or autoimmune liver disease, portal hypertension, were excluded from the study. Patients with cardiac, renal or respiratory diseases, diabetes mellitus or connective tissue disorders were also excluded from the study.

All patients and controls were interviewed and subjected to the following:

Clinical evaluation focusing on confirmed hepatitis C: As regards patients, IgG antibody to hepatitis C virus (anti-HCV) positive by $3^{\text {rd }}$ generation ELISA technique, confirmed by positive Real-Time PCR for $\mathrm{HCV}$ RNA. As regards control subjects, IgG antibody to hepatitis C virus (anti-HCV) negative by $3^{\text {rd }}$ generation ELISA technique.

Laboratory investigations included: Total serum bilirubin and serum albumin, Complete blood count, ALT, AST and ALP, Prothrombin time and international normalization ratio, Complete urine analysis, blood urea, serum creatinine, serum uric acid, Serum cholesterol and TGs, FBS, Serum HBs Ag, HCV antibodies (3rd generation ELISA), HCV-RNA by PCR (both before and after treatment in patients), TSH, ANA, AFP, and antischistosomal antibody.

Routine radiological investigation (Ultrasound examination of the abdomen) was done for all patients and controls.

Other routine investigations: Electrocardiogram, Fundus examination

Histopathological investigations: Liver biopsy was taken, only from patients, before initiation of antiviral combination therapy for histopathological grading and staging according to Metavir scoring system.

Determination of nitric oxide end products (nitrite and nitrate, NOx: The nitrite and nitrate (recently named NOx) concentration was determined by simple Griess reaction. Because the nitric oxide (NO) has a short half life $(2-30 \mathrm{sec})$, it is preferable to determine nitrite, the stable product of NO which may be further oxidized to nitrate. So, the Griess reaction was supplemented with the reduction of nitrate to nitrite by NADPH-dependent nitrate reductase. 


\section{RESULTS}

\section{Viral load in HCV patients before and after treatment $(\mathrm{PCR}) \times 10^{4} \mathrm{IU} / \mathrm{ml}$ (Table 1)}

This table shows that there is a statistically significant difference between responders and NR as regards baseline viral load $p$ value $<0.001$ with Mean \pm SD $\left((113.61 \pm 1.9829) \times 10^{4},(151.66 \pm 1.8250) \times 10^{4}\right)$ respectively, which means higher baseline viral load in NR.

\section{Degree of fibrosis by METAVIR scoring system in both responders and nonresponders (Table 2)}

This table shows that there was a significant difference as regards degree of fibrosis according to Metavir scoring system between responders and nonresponders $(P$ value $=0.027)$. Nonresponders were having higher percentage of $\mathrm{F} 2$ than $\mathrm{F} 1$ among them (70\%, 30\% respectively), while responders were having higher percentage of $\mathrm{F} 1$ than $\mathrm{F} 2$ among them ( $65 \%, 35 \%$ respectively).

\section{NO (total end product) level in different studied groups (Table 3)}

This table shows that there was significant statistical difference in the pre-treatment level of NO between control group and HCV patients $p$ value $(<0.001)$, where the level of NO among control group was higher than among HCV patients groups with Mean \pm SD $(19.48 \pm 2.20)$, while was $(14.75 \pm 2.32)$ and $(16.08 \pm$ $2.15)$ in responder and non responder respectively. After treatment, there was a significant rise in NO level $p$ value $\left(0.016^{*}\right)$ among responders with Mean $\pm \mathrm{SD}(18.08 \pm 2.29)$ than nonresponders with Mean $\pm \mathrm{SD}$ $(17.82 \pm 1.93)$.

\section{Relation between Metavir and PCR in HCV patients groups (Table 4)}

This table shows that there was no relationship between degree of fibrosis and viral load either before or after treatment in responders $p$ value (0.606 and 0.429) respectively, and also in nonresponders $p$ value (0.591 and 0.458 ) respectively.

Correlation between level of NO (total end product) before treatment and viral load before treatment in responders (Table 5)

This table shows that there was no significant correlation between levels of NO (total end product) before treatment and viral load before treatment in responders.

Correlation between level of NO (total end product) before treatment and viral load before treatment in nonresponders (Table 6)

This table shows that there was no significant correlation between levels of NO (total end product) before treatment and viral load before treatment in nonresponders.

Table (1): Comparison between responders and nonresponders as regards viral load both before and after treatment:

\begin{tabular}{||l|l|l|l|l||}
\hline \multirow{2}{*}{} & \multicolumn{3}{|l|}{ Responders } & \multicolumn{2}{l||}{ Non responders } \\
\cline { 2 - 5 } & Before & After & Before & After \\
\hline PCR $\left(\times \mathbf{1 0}^{\mathbf{4}}\right)$ IU/ml & & & & \\
Min. - Max. & $1.30-660.0$ & $0.0-1.30$ & $2.40-750.0$ & $1.03-6500.0$ \\
Mean \pm SD & $113.61 \pm 1.9829$ & $0.28 \pm 0.46$ & $151.66 \pm 1.8250$ & $82.214 \pm 1.51834$ \\
Median & 23.50 & 0.0 & 110.0 & 220.0 \\
\hline $\mathbf{p}_{1}$ & $<0.001^{*}$ & & $<0.001^{*}$ & \\
\hline $\mathbf{p}_{\mathbf{2}}$ & & 0.070 & $<0.001^{*}$ \\
\hline
\end{tabular}

$\mathrm{p}_{1}$ : $\mathrm{p}$ value for Wilcoxon signed ranks test before and afterin responder and non responder

$\mathrm{p}_{2}: \mathrm{p}$ value for Mann Whitney test between responder and non responder in before and after

$*$ : Statistically significant at $\mathrm{p} \leq 0.05$ 
Table (2): Comparison between responders and nonresponders as regards degree of fibrosis (F) according to Metavir scoring system:

\begin{tabular}{|c|c|c|c|c|c|}
\hline & \multicolumn{2}{|c|}{ Responder } & \multicolumn{2}{|c|}{ Non responder } & \multirow{2}{*}{$\mathbf{p}$} \\
\hline & No. & $\%$ & No. & $\%$ & \\
\hline \multicolumn{6}{|c|}{ Metavir } \\
\hline $\mathrm{F} 1$ & 13 & 65.0 & 6 & 30.0 & $0027^{*}$ \\
\hline $\mathrm{F} 2$ & 7 & 35.0 & 14 & 70.0 & \\
\hline
\end{tabular}

P: $p$ value for Chi square test for comparing between the two studied groups

*: Statistically significant at $\mathrm{p} \leq 0.05$

Table (3): Comparison between the different studied groups as regards level of total end product of NO before and after treatment:

\begin{tabular}{|c|c|c|c|c|}
\hline $\begin{array}{l}\text { NOX } \\
\text { (micromol/l) }\end{array}$ & Control & Responder & $\begin{array}{l}\text { Non } \\
\text { responder }\end{array}$ & $\mathbf{p}$ \\
\hline $\begin{array}{l}\text { Before treatment } \\
\text { Min. - Max. } \\
\text { Mean } \pm \text { SD } \\
\text { Median }\end{array}$ & \multirow[t]{3}{*}{$\begin{array}{l}16.0-23.40 \\
19.48 \pm 2.20 \\
19.40\end{array}$} & $\begin{array}{l}10.10-19.60 \\
14.75 \pm 2.32 \\
14.80\end{array}$ & $\begin{array}{l}13.40-22.10 \\
16.08 \pm 2.15 \\
16.10\end{array}$ & \multirow[t]{3}{*}{$<0.001^{*}$} \\
\hline$p_{1}$ & & $<0.001^{*}$ & $<0.001^{*}$ & \\
\hline $\mathbf{p}_{2}$ & & \multicolumn{2}{|l|}{0.176} & \\
\hline $\begin{array}{l}\text { After treatment } \\
\text { Min. - Max. } \\
\text { Mean } \pm \text { SD } \\
\text { Median }\end{array}$ & & $\begin{array}{l}14.40-21.50 \\
18.08 \pm 2.29 \\
18.10\end{array}$ & $\begin{array}{l}13.90-20.60 \\
17.82 \pm 1.93 \\
17.80\end{array}$ & $0.039^{*}$ \\
\hline $\mathbf{p}_{1}$ & & 0.128 & 0.060 & \\
\hline $\mathbf{p}_{2}$ & & \multicolumn{2}{|l|}{0.934} & \\
\hline$\overline{\mathbf{p}_{3}}$ & & $0.016^{*}$ & 0.205 & \\
\hline
\end{tabular}

$\mathrm{p}$ : $\mathrm{p}$ value for $\mathrm{F}$ test (ANOVA) for comparing between the different studied group

$\mathrm{p}_{1}: \mathrm{p}$ value for Post Hoc test (Scheffe) for comparing between control and each other group

$\mathrm{p}_{2}: \mathrm{p}$ value for Post Hoc test (Scheffe) for comparing between responder and non responder

$\mathrm{p}_{3}: \mathrm{p}$ value for Paired t-test between before and after in responder and non responder

*: Statistically significant at $\mathrm{p} \leq 0.05$ 
Table (4): Relation between degree of fibrosis and viral load in HCV patients groups.

\begin{tabular}{|c|c|c|c|c|}
\hline & PCR & F1 & F2 & p \\
\hline \multirow[b]{2}{*}{ 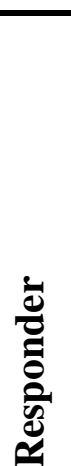 } & $\begin{array}{l}\text { Before }\left(\times \mathbf{1 0}^{4}\right) \\
\text { Min. }- \text { Max. } \\
\text { Mean } \pm \text { SD } \\
\text { Median }\end{array}$ & $\begin{array}{l}1.30-660.0 \\
147.61 \pm 235.27 \\
41.0\end{array}$ & $\begin{array}{l}1.90-230.0 \\
50.47 \pm 81.59 \\
16.0\end{array}$ & 0.606 \\
\hline & $\begin{array}{l}\text { After }\left(\times \mathbf{1 0}^{4}\right) \\
\text { Min. - Max. } \\
\text { Mean } \pm \text { SD } \\
\text { Median }\end{array}$ & $\begin{array}{l}0.0-1300.0 \\
198.46 \pm 400.43 \\
0.0\end{array}$ & $\begin{array}{l}0.0-1200.0 \\
442.86 \pm 565.26 \\
0.0\end{array}$ & 0.429 \\
\hline \multirow[b]{2}{*}{ 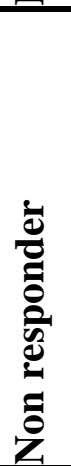 } & $\begin{array}{l}\text { Before }\left(\times \mathbf{1 0}^{4}\right) \\
\text { Min. }- \text { Max. } \\
\text { Mean } \pm \text { SD } \\
\text { Median }\end{array}$ & $\begin{array}{l}7.80-430.0 \\
185.80 \pm 180.84 \\
140.0\end{array}$ & $\begin{array}{l}2.40-750.0 \\
137.03 \pm 187.97 \\
88.0\end{array}$ & 0.591 \\
\hline & $\begin{array}{l}\text { After }\left(\times \mathbf{1 0}^{\mathbf{4}}\right) \\
\text { Min. }- \text { Max. } \\
\text { Mean } \pm \text { SD } \\
\text { Median }\end{array}$ & $\begin{array}{l}0.82-650.0 \\
170.19 \pm 256.12 \\
47.50\end{array}$ & $\begin{array}{l}0.10-180.0 \\
44.51 \pm 57.98 \\
18.19\end{array}$ & 0.458 \\
\hline
\end{tabular}

p: $\mathrm{p}$ value for Mann Whitney test for comparing between the two studied groups

Table (5): Correlation between level of NO (total end product) before treatment and viral load before treatment in responders:

\begin{tabular}{|c|c|c|c|}
\hline & & NOx before & PCR before \\
\hline \multirow[t]{3}{*}{ NOx before } & $\begin{array}{l}\text { Pearson } \\
\text { Correlation(r) }\end{array}$ & 1 & -.422 \\
\hline & Sig. (2-tailed) & & .064 \\
\hline & $\mathrm{N}$ & 20 & 20 \\
\hline \multirow[t]{3}{*}{ PCR before } & $\begin{array}{l}\text { Pearson } \\
\text { Correlation(r) }\end{array}$ & -.422 & 1 \\
\hline & Sig. (2-tailed) & .064 & \\
\hline & $\mathrm{N}$ & 20 & 20 \\
\hline
\end{tabular}

*. Correlation is significant at the 0.05 level (2-tailed). 
Table (6): Correlation between level of NO (total end product) before treatment and viral load before treatment in nonresponders:

\begin{tabular}{||l|l|l|l|}
\hline \multirow{4}{*}{ NOx before } & & NOx before & PCR before \\
\hline & $\begin{array}{l}\text { Pearson } \\
\text { Correlation(r) }\end{array}$ & 1 & -.212 \\
\cline { 2 - 4 } & Sig. (2-tailed) & & $\mathbf{. 3 7 1}$ \\
\cline { 2 - 4 } & $\mathrm{N}$ & 20 & 20 \\
\hline PCR before & $\begin{array}{l}\text { Pearson } \\
\text { Correlation(r) }\end{array}$ & -.212 & 1 \\
\cline { 2 - 4 } & Sig. (2-tailed) & $\mathbf{. 3 7 1}$ & 20 \\
\cline { 2 - 4 } & $\mathrm{N}$ & 20 & \\
\hline
\end{tabular}

*. Correlation is significant at the 0.05 level (2-tailed).

\section{DISCUSSION}

Previous studies were concerned about more interesting predictors of response among genotype $4 \mathrm{HCV}$ patients treated with combined peg- interferon and ribavirin to evaluate their impact on treatment decisions. Thus, we designed the present study aiming to elucidate whether there are certain pre-treatment predictors related to either biochemical, histological or viral factors associated with risk of primary treatment failure in HCV patients by comparing a group of patients with primary failure(non-responders) with a group of patients who reached sustained virological response(responders) by assessment of serum HCV RNA at week $12,24,48,72$ of therapy, focusing on role of pre-treatment level of NO in predicting the probable outcome of treatment strategy.

Nitric oxide is a short highly reactive free radical, influences many physiological processes in virtually every organ and tissue. It diffuses freely across membranes, this attributes making nitric oxide ideal for a transient paracrine and autocrine signaling. ${ }^{[8]}$

Baseline viral load has been considered as a strong independent predictor for achieving SVR.In the current study it was found that there was a statistically significant difference between responders and non responders as regards base line viral load, that it was lower in responders $(113.61 \pm 1.9829) \times 10^{4} \mathrm{IU} / \mathrm{ml}$ than in nonresponders $(151.66 \pm 1.8250) \times 10^{4} \mathrm{IU} / \mathrm{ml}$.

Zeuzem et al. 2006, Berg et al. 2003, and Poynard et al. 1998), mentioned that although viral load does not correlate with the severity of liver injury or the progression of the disease, a low baseline viral load $(600,000-800,000 \mathrm{IU} / \mathrm{ml})$ or less, is an independent predictor of SVR regardless of genotype. ${ }^{[9,10,11]}$ Therefore, they found that patients with pre-treatment high viral loads had worse long-term outcomes than patients with pre-treatment low ones, and the relationship is nonlinear, which is generally matched with the current study results. ${ }^{[9,10,11]}$

As regards histopathological parameters, Liver biopsy is considered the gold standard to assess $\mathrm{HCV}$ infection severity. ${ }^{[12]}$ It also helps to establish the histological grade and stage, which provide prognostic information and help to assess patient's response to antiviral therapy. ${ }^{[12]}$ In this study, there was a significant difference between responders and nonresponders as regards results of liver biopsies taken before initiation of treatment for grading and staging. Increasing degree of fibrosis was obviously more in nonresponders $(\mathrm{F} 1: \mathrm{F} 2=30 \%: 70 \%)$ than in responders $(\mathrm{F} 1: \mathrm{F} 2=65 \%: 35 \%)$.

These results are matched with Everson et al 2006, who showed that the presence of advanced fibrosis and cirrhosis is a major independent predictor of nonresponse to antiviral therapy. ${ }^{[13]}$ In Poynard et al. 
2000, which is a large study of 1744 naive patients with chronic HCV infection undergoing IFN treatment, he found that the presence of no fibrosis or fibrosis limited to the portal tract alone was independently associated with SVR on multivariate analysis. ${ }^{[14]}$

Focusing on relationship between viral load in HCV patients and extent of histopathological damage, this study didn't show any significant relationship between degree of fibrosis and viral load either before or after treatment in both responders and nonresponders.

This result is matched with Altiparmak. E et al 2001 study that was done in Turkey, which found that there was no direct correlation between viral load levels and fibrosis scores in HCV patients. ${ }^{[15]}$ These findings suggest that liver injury in chronic HCV infection is related to immune mediated mechanisms rather than the direct cytopathic effect of the virus. According to this conclusion, the study supposed that laboratory findings cannot take place of histopathological examination as a predictive indicator of liver injury. ${ }^{[15]}$

Some recent studies direct the researchers' attention towards new other predictors of antiviral treatment response, such as level of nitric oxide. Previous studies reported a normal, increased or decreased nitrite concentration in patients' serum with chronic $\mathrm{HCV}$ as in Hokari A et al. ${ }^{[16,17]}$ The reason for these discrepancies remains to be explained. In the present study it was found that there was a significant difference in the post-treatment level of NO between responders and non responders where the level of NO was higher in responders (18.08 \pm 2.29 micromole/liter $)$ than in non responders $(17.82 \pm 1.93$ micromole/liter),in response to pegylated IFN- $\alpha$ a and ribavirin (combination therapy).

These results are matching with Ibrahim et al, study that was done in El Minia, where he found a significant positive correlation between serum NO and virological response, serum NO being higher in responders to pegylated IFN- $\alpha$ plus ribavirin therapy than in NR. ${ }^{[18]}$ Also Bogdan $\mathrm{C}$ et al, reported a significant rise of serum nitrite at two weeks after initiating IFN in SR compared to NR indicating that the rise of serum nitrite was an independent predictive factor for the efficacy of IFN treatment. ${ }^{[19]}$

Comparing the pre-treatment level of serum NO between HCV patients(both responders and nonresponders) and control subjects, this study found that it was significantly higher in control subjects than in patients either responders or nonresponders. On the contrary, Zaki.M study which done in El Mansoura university, reported that serum nitrite and nitrate concentrations among HCV patients were significantly higher than in normal subjects. ${ }^{[20]}$

Findings of this study triggered the researchers to hypothesize the possible use of the NO markers as an independent predictor of virologic response in HCV genotype 4 infected patients. The multivariate logistic regression analysis showed that the rise of serum nitrite during therapy is independent predictive factor for the efficacy of IFN- $\alpha$ plus ribavirin therapy. This can be explained by the fact that,in viral infections, the earliest host responses are non-specific and involve the induction of cytokines including IFNs. ${ }^{[19]}$ It has been found that iNOS is an IFN- $\gamma$-inducible protein in macrophages. Thus, NOS falls into the category of IFNinducible proteins, activated during innate immune response and has a protective effect against viral infection. ${ }^{[19]}$

This study is the first that correlates serum pre-treatment level of NO with pre-treatment viral load to identify the independency of NO as a predictor of response. No significant correlation has been found between these two parameters in both responders and nonresponders, which may support that NO markers may be independent predictors of treatment response.

Finally, as genotype $4 \mathrm{HCV}$ infection is highly endemic in Egypt and considered one of the most important causes of morbidity and mortality, much more researches are needed to make prediction of treatment outcome easier and more accurate.

Conflict of interest: the authors declare no conflict of interest regarding this manuscript.

Financial support: the authors received no financial support regarding this manuscript. 


\section{REFERENCES}

1. WHO. Hepatitis C Fact sheet 164. (Online at: http://www.who.int/mediacentre/factsheets/fs164/en/) 2014.

2. Perz JF, Armstrong GL, Farrington LA, Hutin YJ, Bell BP. The contributions of hepatitis B virus and hepatitis C virus infections to cirrhosis and primary liver cancer worldwide. J Hepatol 2006; 45(4):529-38.

3. Breban R, Doss W, Esmat G, et al. Towards realistic estimates of HCV incidence in Egypt. J Viral Hepat 2013;20:294-296.

4. Mohamoud Y, Mumtaz G, Riome S, Miller D, Abu-Raddad L. The epidemiology of hepatitis C virus in Egypt: a systematic review and data synthesis. BMC Infect Dis 2013;13:288.

5. Lange C, Sarrazin C. Diagnostic Tests in Acute and Chronic Hepatitis C. In: Mauss S, Berg T, Rockstroh J, Sarrazin C, Wedemeyer H (eds). The flying publisher short guide to hepatitis C 2012 edition. German: Flying Publisher \&Kamps; 2012. 28-33.

6. Backus LI, Boothroyd DB, Phillips BR, Belperio P, Halloran J, Mole LA. A sustained virologic response reduces risk of all-cause mortality in patients with hepatitis C. Clin Gastroenterol Hepatol 2011; 9(6):509-16.

7. Sarrazin C, Zeuzem S. Resistance to direct antiviral agents in patients with hepatitis C virus infection. Gastroenterology 2010; 138(2):447-62.

8. Carnovale CE, Ronco MT. Role of nitric oxide in liver regeneration. Ann Hepatol 2012; 11(5):636-47.

9. Zeuzem S, Buti M, Ferenci P. Efficacy of 24 weeks treatment with peginterferon alfa-2b plus ribavirin in patients with chronic hepatitis $\mathrm{C}$ infected with genotype 1 and low pretreatment viremia. J Hepatol 2006; (44):97-103.

10. Berg T, Sarrazin C, Herrmann E. Prediction of treatment outcome in patients with chronic hepatitis C: significance of baseline parameters and viral dynamics during therapy. Hepatology 2003; 37: 600-9.

11. Poynard T, Marcellin P, Lee SS,Niederau C, Minuk GS, Ideo G, et al. Randomized trial of interferon alpha 2 b plus ribavirin for 48 weeks or for 24 weeks versus interferon alpha $2 b$ plus placebo for 48 weeks for treatment of chronic infection with hepatitis C virus. Lancet 1998; 352(9138):1426-32.

12. Navaneethan U, Kemmer N, Neff GW.Predicting the Probable Outcome of Treatment in HCV Patients. TherapAdv Gastroenterol 2009; 2(5):287-302.

13. Everson GT, Hoefs JC, Seeff LB,Bonkovsky HL, Naishadham D, Shiffman ML, et al. Impact of disease severity on outcome of antiviral therapy for chronic hepatitis C: lessons from the HALT-C trial. Hepatology 2006; 44(6):1675-84.

14. Poynard T, McHutchison J, Goodman Z, Ling MH, Albrecht J. Is an 'a la carte' combination interferon alfa- $2 \mathrm{~b}$ plus ribavirin regimen possible for the first line treatment in patients with chronic hepatitis $\mathrm{C}$ ? thealgovirc project group. Hepatology 2000; 31(1):211-8.

15. Altiparmak E, Saritas Ü, Altintas E, TureyenA, Oguz D, Şahin T. Relationship between histological damage, viral load and serum transaminase levels in patients with chronic hepatitis $\mathrm{C}$. The Turkish Journal of Gastroenterology 2001;12(3):185-8.

16. Hokari A, Zeniya M, Esumi H, Ishikawa T, Kurasima Y, Toda G. Role of nitric oxide (NO) in interferon-alpha therapy for hepatitis C. J Infect 2005;51:47-53.

17. Hokari A, Zeniya M, Esumi H, Kawabe T, Gershwin ME, Toda G. Detection of serum nitrite and nitrate in primary biliary cirrhosis: possible role of nitric oxide in bile duct injury. J Gastroenterol Hepatol 2002; 17(3):308-15. 
18. Ibrahim M, Gomaa W, Ibrahim Y, El Hadad H, Shatat M, AleemAA,et al. Nitric oxide levels and sustained virological response to pegylated-interferon alpha2a plus ribavirin in chronic HCV genotype 4 hepatitis: a prospective study. J Gastrointestin Liver Dis 2010; 19(4):387-92.

19. Bogdan C, Rollinghoff M, Diefenbach A. Reactive oxygen and reactive nitrogen intermediates in innate and specific immunity. CurrOpinImmunol 2000; 12(1):64-76.

20. Zaki M, Saudy N, El Diasty A. Study of nitric oxide in patients with chronic hepatitis C genotype 4: Relationship to viremia and response to antiviral therapy. Immunological Investigations 2010; 39(6):598-610. 